UDC 316.77

LBC 60.56

\title{
EUPHEMIZATION OF LEGAL TERMS IN RESPECT OF THE "THIRD AGE": THE NEED AND LIMITS
}

\author{
Yuliya V. Chemeteva \\ Volgograd State University, Volgograd, Russian Federation \\ Marina L. Davydova \\ Volgograd State University, Volgograd, Russian Federation
}

\begin{abstract}
The article deals with the problem of "roughness" of some legal terms used in the pension legislation of the Russian Federation, as well as in the legislation establishing rules for people with disabilities. There are extracts from various legal sources, where such incorrect terms as "period of survival", "age of survival", "grandfather", "grandmother", "invalid", "old age pension", "age", etc. The incorrect use of those terms is analyzed from the point of view of modern linguistic and social developments. The positive and negative aspects of the use of diminutive forms as a way to mitigate the "rough" legal terminology are substantiated. As a means of adaptation of outdated and having become discordant terms such stylistic device as euphemization is considered, which allows to construct a neutral or positive connotation of the legal term. Examples of the use of euphemisms in legislative texts are given, and their adequacy in terms of political correctness and modern language trends is analyzed. It is noted that the tendency to euphemization is peculiar to the Russian pension legislation, however, today it is not fully realized. Examples of "smoothing" of rough terms in legislative acts are given, in particular, softening of the term "old age" in Federal laws "on labor pensions in the Russian Federation" and "on state pension provision in the Russian Federation". Social factors (increase in life expectancy of people, period of their working capacity, quality of life) influencing change of understanding of connotative meaning of the term "old age" are pointed out. Possible variants of the euphemization of the term "old-age pension" in the pension legislation are proposed allowing to replace this term with a more harmonious word.

Key words: legal term, euphemism, the old-age pension, period of survival, the disabled, people with disabilities, the "third age", political correctness.
\end{abstract}

УДК 316.77

ББК 60.56

\section{ЭВФЕМИЗАЦИЯ ЮРИДИЧЕСКИХ ТЕРМИНОВ В ОТНОШЕНИИ «ТРЕТЬЕГО ВОЗРАСТА»: НЕОБХОДИМОСТЬ И ПРЕДЕЛЫ}

\author{
Юлия Владимировна Чеметева \\ Волгоградский государственный университет, г. Волгоград, Российская Федерация \\ Марина Леонидовна Давыдова \\ Волгоградский государственный университет, г. Волгоград, Российская Федерация
}

Аннотация. В данной статье рассматривается проблема «грубости» некоторых юридических терми-
нов, используемых в пенсионном законодательстве Российской Федерации, а также в законодательстве, уста-
навливающем правила в отношении людей с ограниченными возможностями. Приводятся выдержки из
различных нормативных источников, в которых встречаются такие некорректные термины, как «срок дожи-
тия», «возраст дожития», «дед», «бабка», «инвалид», «пенсия по старости», «старость» и т. д. Некоррект-
ность использования упомянутых терминов анализируется с точки зрения современных языковых и соци-
альных тенденций. Обосновываются позитивные и негативные стороны использования уменьшительно-лас-
кательных форм как способа смягчения «грубой» нормативно-правовой терминологии. Как средство адап-
тации устаревших и ставших неблагозвучными терминов рассматривается такой стилистический прием, как 
эвфемизация, которая позволяет конструировать нейтральную или положительную коннотацию юридического термина. Приводятся примеры использования эвфемизмов в законодательных текстах, а также анализируется их адекватность с точки зрения политкорректности и современных языковых тенденций. Отмечается, что российскому пенсионному законодательству свойственна тенденция к эвфемизации, однако на сегодняшний день реализована она не в полной мере. Приводятся примеры «сглаживания» грубых терминов в законодательных актах, в частности, смягчения термина «старость» в федеральных законах «О трудовых пенсиях в Российской Федерации» и «О государственном пенсионном обеспечении в Российской Федерации». Выделяются социальные факторы (увеличение продолжительности жизни людей, периода их работоспособности, качества жизни), оказавшие влияние на изменение понимания коннотативного значения термина «старость». Предлагаются возможные варианты эвфемизации термина «пенсия по старости» в пенсионном законодательстве, позволяющие заменить данный термин более благозвучным словом.

Ключевые слова: юридический термин, эвфемизм, пенсия по старости, срок дожития, инвалид, люди с ограниченными возможностями здоровья, «третий возраст», политическая корректность.

Важным направлением исследований на стыке социологии и права является законодательная социология, основоположниками которой считаются Г. Спенсер [22, с. 131] и Ж. Карбонье [7, с. 338], а среди отечественных ученых - В.П. Казимирчук, В.Н. Кудрявцев, В.В. Лапаева, С.В. Поленина и другие [6; 10]. Социологические исследования, в том числе на предзаконодательном и постзаконодательном этапах, позволяют выбрать оптимальный вариант правового регулирования, обеспечить позитивное восприятие населением новых законов, норм, правил и тем самым повысить эффективность правотворческой работы. В числе многих факторов, оказывающих существенное влияние на то, как обществом воспринимаются законодательные тексты, какие дополнительные коннотации может видеть гражданин, читая выдержки из нового законопроекта, изучая содержание приказа, распоряжения или справки, выданной ему госучреждением, значительное место занимает языковое качество данных текстов. Более или менее удачный подбор терминов и тщательная проработка их контекстного окружения может не только повлиять на понятность правовых велений для людей, но и запрограммировать их положительное или отрицательное отношение к самим этим велениям.

Юридический термин обладает прагматическими свойствами, которые содержатся в его эмоциональной составляющей $[17$, с. 26]. Соответственно в зависимости от того, как данная эмоциональная составляющая воспринимается социумом, реализуется прагматический компонент термина. Восприятие обществом того или иного слова или словосочетания, выс- тупающего в законодательном тексте в качестве термина, также зависит от общих лингвистических тенденций, господствующих в литературном языке в конкретный период времени. Лексический стиль любых текстов (в частности юридических документов) меняется с течением времени, что детерминируется комплексом различных лингвистических и экстралингвистических факторов, связанных с менталитетом, культурой и традициями носителей конкретного языка, а также с процессами и явлениями, происходящими в обществе и отражающимися на речевом поведении граждан и системе языка, функционирующей в данном социуме. Тогда как отдельные черты и лексическая наполняемость любого стиля меняются с течением времени, некоторые особенности и требования, предъявляемые стилем к текстам, остаются неизменными.

Тексты нормативно-правовых актов излагаются в официально-деловом стиле, чертами которого являются объективность, точность, безоценочность и безэмоциональность. Соответствуя данным критериям, многие юридические термины, однако, звучат достаточно грубо по отношению к тем или иным группам лиц. Проблема заключается в том, что для адекватного звучания и восприятия языка закона массовым сознанием необходимо также соответствие его таким критериям, как понятность, образность, стабильность, самобытность, близость к обиходному языку [23, с. 18]. Так, термины, используемые в законодательных текстах, должны соответствовать не только критериям, задаваемым официально-деловым стилем, но также быть более-менее понятными, благозвучными. 
Говоря об адекватности и благозвучности юридических терминов и об их соответствии критериям, упомянутым выше, следует также принять во внимание тот факт, что в настоящее время широкое распространение получает мощная культурно-поведенческая тенденция, именуемая «политическая корректность» [3]. Обозначая стиль речи, минимизирующий оскорбление или притеснение какихлибо групп и исключающий любого рода дискриминацию, политкорректность оказывает существенное влияние на лексическую наполняемость текстов, предназначенных для широкой аудитории, и в особенности текстов, касающихся политических, социальных и экономических аспектов жизни общества. По утверждению С.Г. Тер-Минасовой, политическая корректность языка выражается в стремлении найти новые способы языкового выражения взамен тех, которые задевают чувства и достоинство индивидуума, ущемляют его человеческие права привычной языковой бестактностью и/или прямолинейностью в отношении расовой и половой принадлежности, возраста, состояния здоровья, социального статуса, внешнего вида и т. д. [24, с. 137].

Перечислив те факторы, которые могут оказывать влияние на употребляемость определенных юридических терминов в законодательных текстах, перейдем к рассмотрению примеров из различных нормативно-правовых актов, которые можно расценить как неблагозвучные или грубые по отношению к определенной группе лиц.

Так, например, в постановлении Правительства РФ № 531 от 2 июня 2015 г. используется термин «срок дожития» [14]. Данный термин определяют как устанавливаемый государством на основании статистики средний срок жизни гражданина после выхода на заслуженный отдых [19]. С лингвистической точки зрения слово «дожитие» обладает негативной коннотацией, ставящей под сомнение полноценность жизни людей почтенного возраста. Вместо представления о том, что человек находится на заслуженном отдыхе, при воспроизведении термина всплывает ассоциация того, что человек будто бы «доживает» отведенный ему срок, то есть близок к смерти. Вследствие данной ассоциации тот самый жизненный период, обозначаемый термином «срок дожития», истолковывается в первую очередь негативно, как некий неполноценный период жизни человека, находясь в котором, он «доживает», будто бы пребывая в ожидании смерти, а не живет и радуется жизни. Таким образом, данный термин можно считать достаточно грубым по отношению к пожилым людям.

Схожее словосочетание встречается и в методических указаниях «Состояние здоровья населения в связи с состоянием природной среды и условиями проживания населения...»: «максимальный возраст дожития» [21]. В данном документе рассматриваемый нами термин используется для обозначения переменной в формуле расчета коэффициента избыточного пожизненного радиационного риска онкологической заболеваемости. В страховом законодательстве также используется термин с подобным коннотативно отрицательным компонентом: «показатель дожития» [13]. Подобные термины могут задевать чувства определенной категории лиц, поэтому их стилистически нейтральные эквиваленты были бы более приемлемы для использования в законодательных текстах.

Стоит отметить, что в действующем российском законодательстве последних лет прослеживается тенденция замены некоторых грубых и неблагозвучных терминов на более нейтральные. Как уже было ранее замечено, язык под действием множества факторов меняется с течением времени, меняется и актуальный лексический состав юридического дискурса, что вызывает необходимость вносить изменения в нормативно-правовые акты. Некоторые слова или словосочетания, вполне благозвучные ранее, сейчас содержат отрицательные компоненты, появившиеся вследствие определенных языковых тенденций, а также под действием многих экстралингвистических и социальных факторов. Подобные отрицательные компоненты или коннотации формируются в сознании общества годами, вследствие чего нейтральный термин постепенно начинает восприниматься как грубый. Во многих случаях, когда слово приобретает негативный оттенок значения, трудно сказать, что именно стало тому причиной и когда именно слово стало вызывать негативные ассоциации. Тем не менее в законодательстве такой термин употребляться уже не может, и на смену ему приходит нейтральный эквивалент, не вызывающий отрицательных ассоциаций. 
Так, например, термины «дед» и «бабка», которые ранее часто встречались в законодательных актах, сейчас можно увидеть только в некоторых международных договорах: «Осужденный, а также его представитель или близкие родственники (супруг, родители, дети, усыновители, усыновленные, родные братья и сестры, дед, бабка, внуки) вправе обратиться к компетентным органам любой из Договаривающихся Сторон с просьбой о рассмотрении возможности направления запроса о передаче» [4]. В Семейном кодексе Российской Федерации данные термины заменены на «дедушка» и «бабушка» соответственно [18]. В соответствии с господствующими языковыми тенденциями и распространением культурно-поведенческого принципа политической корректности на все сферы социальной жизни, такие варианты более приемлемы для использования в законодательных текстах. Для адаптации традиционно использовавшихся терминов «дед» и «бабка» к современной языковой и социальной картине потребовалась их трансформация в уменьшительно-ласкательную форму, что, однако, далеко не во всех случаях применимо в качестве средства смягчения ставшей грубой нормативно-правовой терминологии.

Лексикология выделяет следующие тенденции изменения лексического значения слова: сужение или расширение значения слова; улучшение или ухудшение (pejoration) значения слова [12, с. 362]. Все упомянутые тенденции так или иначе сказываются на восприятии слов и словосочетаний обществом. Подвергшиеся ухудшению значения слова со временем становятся менее благозвучными. Именно данная тенденция изменения лексического значения, наблюдаемая в ситуации с терминологией законодательных текстов, рассматривается в рамках затронутой нами проблемы наряду с тенденцией усиления политической корректности во всех сферах жизни общества.

Так, например, слово «инвалид» ранее не имело каких-либо отрицательных коннотативных компонентов в своем значении. В XIX в. в России инвалидами называли старых солдат, неспособных к строевой военной службе. Часто это означало то же, что ветеран (у А.С. Пушкина: «Гарнизон крепости состоял из нескольких десятков старых инвалидов» [16, с. 293]). Значение физической увечности появилось у данного слова позже. При этом сейчас в обыденном языке слово может иметь уничижительное значение «калека», «слабый», «убогий» [20, с. 114]. Если ранее данный термин использовался в законодательных текстах как нейтральный, в современном восприятии он обретает некие отрицательные коннотации неполноценности, ущемленности. Вследствие этого как в международном, так и в российском законодательстве сейчас для данного термина подобраны более приемлемые и отвечающие современной языковой картине и требованиям политкорректности синонимы. Прежде чем привести данные синонимы, представляется целесообразным рассмотреть языковое средство, с помощью которого они были образованы.

Когда некоторые слова постепенно становятся менее употребляемыми, им на смену приходят их более нейтральные и благозвучные эквиваленты, образованные с помощью различных языковых средств. Помимо упоминаемой ранее трансформации в уменьшительно-ласкательную форму такими средствами часто выступают эвфемизмы. Эвфемизм стилистически нейтральное слово или выражение, употребляемое вместо синонимичной языковой единицы, которая представляется говорящему неприличной, грубой или нетактичной. Использование эвфемизмов «позволяет завуалировать истинную сущность явления в связи с возможностью создания нейтральной или положительной коннотации» [1, с. 614]. При помощи эвфемизмов мысль выражается мягче, негативный эффект оттеняется, что помогает более нейтрально выразить какое-либо понятие или сместить акцент с негативной смысловой составляющей термина.

В случае со словом «инвалид» проблема отрицательных коннотаций, имеющихся на настоящее время в данной языковой единице, решилась путем эвфемизации данного понятия: слово теперь заменяет стилистически нейтральное словосочетание «человек с ограниченными возможностями здоровья». Данный эвфемизм был очень активно воспринят деловой культурой и вошел в обиход. Термин «человек с ограниченными возможностями здоровья» широко используется в международных актах (disabled people), а также в российском законодательстве. Например, в Федеральном законе «Об образовании в Россий- 
ской Федерации» [25], Федеральном законе «О физической культуре и спорте в Российской Федерации» [30] и т. д.

Однако следует заметить, что российское законодательство, приняв современный политкорректный эвфемизм «люди с ограниченными возможностями здоровья», не исключило из своих текстов слово «инвалид». Мы можем обнаружить следующие примеры употребления данного слова, имеющего негативный компонент: «физическая реабилитация инвалидов и лиц с ограниченными возможностями здоровья» [30]; «доступность для инвалидов и других групп населения с ограниченными возможностями передвижения» [31]; «Содержание образования и условия организации обучения и воспитания обучающихся с ограниченными возможностями здоровья определяются адаптированной образовательной программой, а для инвалидов также в соответствии с индивидуальной программой реабилитации инвалида...» [25].

То, как законодательство разграничивает термины «инвалид» и «человек с ограниченными возможностями здоровья», остается непонятным. Критерием подобного разграничения могло бы стать наличие специального правового статуса человека, обозначаемого в законодательстве как «инвалид», однако в дефиниции, закрепленной в Федеральном законе «О социальной защите инвалидов в Российской Федерации», специфические юридические характеристики понятия «инвалид» не упоминаются: «Инвалид - лицо, которое имеет нарушение здоровья со стойким расстройством функций организма, обусловленное заболеваниями, последствиями травм или дефектами, приводящее к ограничению жизнедеятельности и вызывающее необходимость его социальной защиты» [28]. В отсутствие юридических различий между понятиями «инвалид» и «человек с ограниченными возможностями здоровья» сочетание двух стилистически неравных терминов в российском законодательстве представляется нам неоправданным. Однако сам факт появления в нормативных текстах эвфемизма подтверждает тенденцию к смягчению грубости нормативных текстов и используемых в них юридических терминов.

Необходимо заметить, что описываемая выше тенденция к эвфемизации неблагозвучных юридических терминов пока еще не затронула пенсионное законодательство. Так, в Федеральном законе «О трудовых пенсиях в Российской Федерации» [29] и Федеральном законе «О государственном пенсионном обеспечении в Российской Федерации» [27] широко используется термин «пенсия по старости». На фоне общей тенденции к усилению политкорректности, в том числе нормативных текстов, встает вопрос о приемлемости данного термина. Нет сомнения в том, что слово «старость» в настоящее время не вызывает положительных ассоциаций у граждан РФ, в особенности у людей, уже достигших пенсионного возраста. Для иллюстрации того факта, что слово «старость» обладает отрицательной коннотацией и воспринимается людьми XXI в. как нечто пугающее, нам представляется целесообразным привести определение данного слова, представленное в энциклопедии практической психологии «Психологос»: «Старость период жизни человека от утраты способности организма к продолжению рода до смерти. Характеризуется ухудшением здоровья, умственных способностей, угасанием функций организма» [8, с. 324]. Данное определение не оставляет сомнений, что термин «пенсия по старости» является грубым для соответствующей категории граждан, и поэтому в настоящее время не может считаться приемлемым к использованию в законодательстве.

Рассматривая же этимологическое значение слова «старость», мы не видим отрицательного компонента. Согласно этимологическому словарю Г.А. Крылова, слово «старый» является общеславянским, имеет индоевропейскую природу (в древнеиндийском sthiras - «крепкий»), восходит к той же основе, что и глагол «стать» [9, с. 336]. Изначальное отсутствие отрицательной коннотации в слове «старость» свидетельствует о том, что термин «пенсия по старости» приобрел отрицательное коннотативное значение со временем, потеряв свою нейтральность вследствие языковых тенденций смещения лексического значения в сторону ухудшения.

В изменении понимания обществом слова «старость» также играет роль социальный фактор: продолжительность жизни людей увеличивается, дольше сохраняется их работоспособность, люди дольше остаются молодыми, ведут здоровый образ жизни, активно про- 
являют себя в социуме. Тот возраст, который сто лет назад можно было назвать старостью (55-60 лет), сейчас ею не является. Многие люди, выходя на пенсию, занимают еще более активную гражданскую позицию, а благодаря появлению массы свободного времени продолжают заниматься общественной деятельностью или только начинают проявлять себя в каких-либо инициативах, находят хобби, путешествуют, занимаются саморазвитием, воспитанием внуков, что характеризует их как социально активных граждан. Рассматриваемый нами возраст, грубо именуемый в законодательстве старостью, следовало бы обозначить более положительным словом или словосочетанием, вызывающим ассоциации со сменой основной деятельности человека, предполагающей больше отдыха, или вовсе нейтральным, более абстрактным словом. Также мы полагаем, что термин «пенсия по старости», используемый в законодательстве, было бы приемлемо заменить более благозвучным эвфемизмом.

Безусловно, попытки «сглаживания» грубых терминов в юридических текстах предпринимались и раньше: провозглашенный на 45-й сессии Генеральной Ассамблеи $\mathrm{OOH}$ Международный день престарелых в русскоязычных документах $\mathrm{OOH}$ был заменен на Международный день пожилых людей (отмечается 1 октября). Конечно, слово «пожилой» несколько мягче по сравнению со словом «старый», однако его нельзя назвать стилистически нейтральным, так как в нем присутствует отрицательный коннотативный компонент (пожилой - уже достаточно поживший). В англоязычных документах для обозначения Международного дня престарелых был подобран эвфемизм: International Day of Older Persons. Словосочетание Older Persons является стилистически нейтральным и не содержит таких отрицательных коннотаций, как русскоязычные синонимы «пожилой» и «престарелый». Также в английском языке существует словосочетание senior citizen, являющееся еще более благозвучным и мягким по отношению к людям «третьего возраста» и постепенно входящее в широкое употребление.

В последнее десятилетие в английском языке усилилась тенденция замены слов, не соответствующих политически корректным пред- ставлениям общества, «инклюзивными» терминами [5, с. 48]. Так называемые инклюзивные термины, образованные путем эвфемизации, смягчают различные виды дискриминации. Тенденция смягчения возрастной дискриминации в английском языке заслуживает особого внимания: существует даже термин ageism, определяемый как притеснение людей определенного возраста. Термин third age, который также можно считать инклюзивным, обозначает период жизни от 65 лет и далее. Во избежание употребления слова old (старый) для обозначения людей почтенного возраста в английском языке употребляются в последнее время такие эвфемизмы, как senior, mature, seasoned [3].

Процессы и явления, происходящие в обществе, находят свое отражение в речевом поведении граждан, что спустя какое-то время также оказывает влияние на лексическую наполняемость юридических текстов и употребляемость определенных терминов в законодательстве. Как еще один более благозвучный вариант слова «старый» в Федеральном законе «О введении в действие части третьей Гражданского кодекса Российской Федерации» используется эвфемизм «преклонный возраст» [26]. Однако в лексическом значении слова «преклонный» содержатся такие компоненты, как «перешагнувший через зрелые года», «приближающийся к глубокой старости, к смерти». В силу наличия подобных отрицательных коннотаций в значении словосочетания данную попытку заменить слово «старый» более благозвучным и нейтральным эвфемизмом можно считать неудачной.

Следует также обратить внимание на существующую в русском языке практику называть пожилых людей людьми «третьего возраста» по аналогии с англоязычным политкорректным эвфемизмом third age [2]. Данный эвфемизм является наиболее благозвучным в сравнении с ранее упомянутыми. Однако для законодательных текстов его использование было бы не оправдано: словосочетание метафорично и стилистически окрашено, что препятствует его использованию в юридических документах, стиль которых предполагает объективность, точность, безоценочность и безэмоциональность лексических средств.

Как видим, достаточно строгие рамки официально-делового стиля препятствуют употреб- 
лению некоторых эвфемизмов в законодательных текстах. Язык, откликаясь на тенденцию усиления политкорректности, открывает массу возможностей для людей именовать явления и факты новыми терминами, создавать более благозвучные словосочетания, подбирать более мягкие синонимы, эвфемизировать ставшие грубыми термины. Однако сдержанный стиль юридических текстов позволяет использовать в законодательстве только те нейтральные термины, которые также отвечают таким критериям, как объективность, точность, безоценочность и безэмоциональность.

Вероятно, оптимальным вариантом с точки зрения современного звучания, соображений политкорректности и тех требований, которые предъявляются к языку правовых актов, стоит признать конструкцию «люди старшего возраста» [11], используемую в официальной риторике последних лет наряду со словосочетаниями «люди пожилого возраста» и «люди старшего поколения».

Возвращаясь к термину «пенсия по старости», необходимо также констатировать, что он нуждается в замене компонента, со временем потерявшего свою благозвучность и подвергшегося ухудшению лексического значения. Однако заметим, что данный термин продолжает употребляться в законодательных актах, например, в недавно вышедшем проекте Федерального закона «О внесении изменений в отдельные законодательные акты Российской Федерации по вопросам назначения и выплаты пенсий» [15]. Как нами уже было ранее замечено, наличие отрицательных коннотаций в значении термина требует его замены благозвучным синонимом. В рамках официально-делового стиля следует подобрать наиболее нейтральный вариант, подходящий как по сочетанию коннотативного и денотативного значения, так и по стилистическим характеристикам. На сегодняшний день наиболее приемлемым вариантом данного термина может служить, на наш взгляд, словосочетание «пенсия по возрасту». Данная языковая единица является стилистически нейтральной, отвечает требованиям официально-делового стиля, не предполагая оценки или некого эмотивного компонента, а также вполне соответствует нормам политической корректности.

Проанализировав некоторые употребляющиеся в российском законодательстве тер- мины на предмет политкорректности, мы постарались разобраться в том, какие факторы влияют на приемлемость употребления того или иного термина в нормативно-правовых актах, что является причиной присутствия грубых терминов в законодательных текстах, а также предположили, какими нейтральными и более благозвучными эквивалентами можно их заменить. Однако важно понимать, что и термины, рассмотренные выше, как и другие - вполне знакомые и адекватно звучащие - со временем могут существенно измениться в восприятии людей под влиянием языковых или социальных тенденций. Юридический язык, несмотря на свойственную ему консервативность, в конечном итоге не может игнорировать эти тенденции, поэтому нуждается в периодической актуализации терминологии.

\section{СПИСОК ЛИТЕРАТУРЫ}

1. Арапова, Н. С. Эвфемизмы // Лингвистический энциклопедический словарь / гл. ред. В. Н. Ярцева. - М. : Сов. энцикл., 1990. -683 с.

2. Борисов, Г. И. Психологические характеристики пожилых людей третьего возраста / Г. И. Борисов // Педагогическое образование в России. - 2016. № 5. - Электрон. текстовые дан. - Режим доступа: https://cyberleninka.ru/article/n/psihologicheskieharakteristiki-pozhilyh-lyudey-tretiego-vozrasta (дата обращения: 26.08.2018). - Загл. с экрана.

3. Буйнова, О. Ю. Языковые средства политкорректности в английском языке / О. Ю. Буйнова // Многоязычие в образовательном пространстве. - 2010. № 2. - Электрон. текстовые дан. - Режим доступа: https://cyberleninka.ru/article/n/yazykovye-sredstvapolitkorrektnosti-v-angliyskom-yazyke (дата обращения: 26.08.2018). - Загл. с экрана.

4. Договор между Российской Федерацией и Монголией о правовой помощи и правовых отношениях по гражданским и уголовным делам (ред. от 12.09.2002). - Доступ из справ.-правовой системы «КонсультантПлюс» (дата обращения: 06.05.2018).

5. Заботкина, В. И. Новая лексика современного английского языка / В. И. Заботкина. - М. : Высш. шк., 1989. - 128 с.

6. Казимирчук, В. П. Социальный механизм действия права / В. П. Казимирчук // Советское государство и право. - 1970. - № 10. - С. 37-44.

7. Карбонье, Ж. Юридическая социология / Ж. Карбонье. - М. : Прогресс, 1986. - 352 с. 
8. Козлов, Н. И. Психологос. Энциклопедия практической психологии / Н. И. Козлов. - М. : Эксмо, 2016. -752 c.

9. Крылов, П. А. Этимологический словарь русского языка / П. А. Крылов. - СПб. : Полиграфуслуги, 2005. - 432 с.

10. Лапаева, В. В. Общественное мнение и законодательство / В. В. Лапаева // Социологические исследования. - 1997. - № 9. - С. 16-28.

11. Москва создает новые возможности для горожан старшего возраста (Круглый стол по программе «Активное долголетие») // Официальный сайт Московской городской думы. - Электрон. текстовые дан. - Режим доступа: https://duma.mos.ru/ru/0/news/ novosti/moskva-sozdaet-novyie-vozmojnosti-dlyagorojan-starshego-vozrasta (дата обращения: 15.05.2018). - Загл. с экрана.

12. Пауль, Г. Принципы истории языка / Г. Пауль. - М. : Изд-во иностр. лит., 1960. - 500 с.

13. Постановление от 03 апр. 2014 г. по делу № А58-6295/2012 // Судебные и нормативные акты РФ. - Электрон. текстовые дан. - Режим доступа: https:/www.sudact.ru/arbitral/doc/CuYjaGF8YTLw/ (дата обращения: 25.08.2018). - Загл. с экрана.

14. Постановление Правительства РФ «Об утверждении методики оценки ожидаемого периода выплаты накопительной пенсии» от 02 июня 2015 г. № 531. - Доступ из справ.-правовой системы «КонсультантПлюс» (дата обращения: 06.05.2018).

15. Проект Федерального закона № 489161-7 «О внесении изменений в отдельные законодательные акты Российской Федерации по вопросам назначения и выплаты пенсий». - Доступ из справ.правовой системы «КонсультантПлюс» (дата обращения: 01.09.2018).

16. Пушкин, А. С. Капитанская дочка / А. С. Пушкин // Собр. соч. В 10 т. Т. 5 / А. С. Пушкин. - М., 1959-1962. - С. 286-411.

17. Салтыков, Г. К. Прагматические свойства юридических терминов / Г. К. Салтыков // Современное право. - 2015. - № 8. - С. 26-31.

18. Семейный кодекс Российской Федерации от 29 дек. 1995 г. № 223-Ф3 (ред. от 29 дек. 2017) // Сборник основных федеральных законов РФ. Электрон. текстовые дан. - Режим доступа: https:// fzrf.su/kodeks/sk/ (дата обращения: 01.09.2018). Загл. с экрана.

19. Слободян, Е. Что такое срок дожития? / Е. Слободян // Аргументы и факты. - 2016. 26 мая. - Электрон. текстовые дан. - Режим доступа: http://www.aif.ru/dontknows/actual/chto takoe_srok_dozhiti (дата обращения: 07.05.2018). Загл. с экрана.

20. Словарь русских синонимов и сходных по смыслу выражений // под ред. Н. Абрамова. - М. : Русские словари, 1999. - 433 с.
21. Состояние здоровья населения в связи с состоянием природной среды и условиями проживания населения. Оценка радиационного риска у населения за счет длительного равномерного техногенного облучения в малых дозах. Методические указания (МУ 2.1.10.3014-12. 2.1.10). - Доступ из справ.-правовой системы «КонсультантПлюс» (дата обращения: 06.05.2018).

22. Спенсер, Г. Грехи законодателей / Г. Спенсер // Социологические исследования. - 1992. № 2. - C. 129-136.

23. Тарасевич, И. Б. Адекватность языка закона : автореф. дис. ... канд. юрид. наук / Тарасевич Илья Борисович. - М., 2018. - 28 с.

24. Тер-Минасова, С. Г. Язык и межкультурная коммуникация / С. Г. Тер-Минасова. - М. : Слово, 2000. -261 с.

25. Федеральный закон «Об образовании в Российской Федерации» от 29 дек. 2012 г. № 273-ФЗ (ред. от 29 дек. 2017) // Официальные сетевые ресурсы Президента России. - Электрон. текстовые дан. Режим доступа: http://kremlin.ru/acts/bank/36698 (дата обращения: 27.08.2018). - Загл. с экрана.

26. Федеральный закон «О введении в действие части третьей Гражданского кодекса Российской Федерации» от 26 нояб. 2001 г. № 147-Ф3. - Доступ из справ.-правовой системы «КонсультантПлюс» (дата обращения: 07.05.2018).

27. Федеральный закон «О государственном пенсионном обеспечении в Российской Федерации» от 15 дек. 2001 г. № 166-Ф3 (ред. от 18 июля 2017 г.). - Доступ из справ.-правовой системы «КонсультантПлюс» (дата обращения: 07.05.2018).

28. Федеральный закон «О социальной защите инвалидов в Российской Федерации» от 24 нояб. 1995 г. № 181-Ф3 (ред. от 29 дек. 2017 г.). - Доступ из справ.-правовой системы «КонсультантПлюс» (дата обращения: 06.05.2018).

29. Федеральный закон «О трудовых пенсиях в Российской Федерации» // Российская газета. 2001. - № 2859. - Электрон. текстовые дан. - Режим доступа: https://rg.ru/2001/12/20/zakonpensii-dok.html (дата обращения 07.05.2018). - Загл. с экрана.

30. Федеральный закон «О физической культуре и спорте в Российской Федерации» от 4 дек. 2007 г. № 329-Ф3 (ред. от 05 дек. 2017 г.) // Сборник федеральных законов РФ. - Электрон. текстовые дан. Режим доступа: https://frf.su/zakon/o-fizicheskojkulture-i-sporte-329-fz (дата обращения: 01.09.2018). Загл. с экрана.

31. Федеральный закон «Технический регламент о безопасности зданий и сооружений» от 30 дек. 2009 г. № 384-Ф3 (ред. от 02 июля 2013 г.). Доступ из справ.-правовой системы «КонсультантПлюс» (дата обращения 23.08.2018). 


\section{REFERENCES}

1. Arapova N.S. Evfemizmy. Lingvisticheskiy entsiklopedicheskiy slovar [Euphemisms. Linguistic Encyclopedic Dictionary]. Moscow, Sov. entsikl. Publ., $1990.683 \mathrm{p}$.

2. Borisov G.I. Psikhologicheskie kharakteristiki pozhilykh lyudey tretyego vozrasta [Psychological Characteristics of Elderly People of the Third Age]. Pedagogicheskoe obrazovanie $v$ Rossii, 2016, no. 5. URL: https://cyberleninka.ru/article/n/psihologicheskieharakteristiki-pozhilyh-lyudey-tretiego-vozrasta. (accessed August 26, 2018).

3. Buynova O.Yu. Yazykovye sredstva politkorrektnosti $\mathrm{v}$ angliyskom yazyke [Language Means of Political Correctness in English]. Mnogoyazychie v obrazovatelnom prostranstve, 2010, no. 2. URL: https://cyberleninka.ru/article/n/ yazykovye-sredstva-politkorrektnosti-v-angliyskomyazyke (accessed August 26, 2018).

4. Dogovor mezhdu Rossiyskoy Federatsiey $i$ Mongoliey o pravovoy pomoshchi $i$ pravovykh otnosheniyakh po grazhdanskim i ugolovnym delam (red. ot 12.09.2002) [Agreement between the Russian Federation and Mongolia on Legal Assistance and Legal Relations on Civil and Criminal Cases (ed. of 12 September 2002)]. Access from Reference Legal System 'KonsultantPlyus'(accessed May 6, 2018).

5. Zabotkina V.I. Novaya leksika sovremennogo angliyskogo yazyka [New Vocabulary of Modern English]. Moscow, Vysshaya shkola Publ., 1989. 128 p.

6. Kazimirchuk V.P. Sotsialnyy mekhanizm deystviya prava [Social Mechanism of Law]. Sovetskoe gosudarstvo i pravo, 1970, no. 10, pp. 37-44.

7. Carbonier J. Yuridicheskaya sotsiologiya [Legal Sociology]. Moscow, Progress Publ., 1986. 352 p.

8. Kozlov N.I. Psikhologos. Entsiklopediya prakticheskoy psikhologii [Psychologos. Encyclopedia of Practical Psychology]. Moscow, Eksmo Publ., 2016. 752 p.

9. Krylov P.A. Etimologicheskiy slovar russkogo yazyka [Etymological Dictionary of the Russian Language]. Saint Petersburg, Poligrafuslugi Publ., 2005. 432 p.

10. Lapaeva V.V. Obshchestvennoe mnenie i zakonodatelstvo [Public Opinion and Legislation]. Sotsiologicheskie issledovaniya, 1997, no. 9, pp. 16-28.

11. Moskva sozdaet novye vozmozhnosti dlya gorozhan starshego vozrasta (Kruglyy stol po programme «Aktivnoe dolgoletie») [Moscow Creates New Opportunities for Older Citizens (Round Table on Active Longevity Program)]. Ofitsialnyy sayt Moskovskoy gorodskoy dumy [The Official Website of the Moscow City Duma]. URL: https://duma.mos.ru/ru/0/news/ novosti/moskva-sozdaet-novyie-vozmojnosti-dlyagorojan-starshego-vozrasta. (accessed May 15, 2018).
12. Paul H. Printsipy istorii yazyka [Principles of the History of Language]. Moscow, Izd-vo inostrannoy literatury, 1960.500 p.

13. Postanovlenie ot 03 apr. 2014 g. po delu № A58-6295/2012 [Decree of April 3, 2014 on Case no. A58-6295/2012]. Sudebnye i normativnye akty RF [Judicial and Normative Acts of the Russian Federation]. URL https://www.sudact.ru/arbitral/doc/ CuYjaGF8YTLw/ (accessed August 26, 2018).

14. Postanovlenie Pravitelstva $R F \ll O b$ utverzhdenii metodiki otsenki ozhidaemogo perioda vyplaty nakopitelnoy pensii» ot 02 iyunya $2015 \mathrm{~g}$. № 531 [Decree of the Government of the Russian Federation 'On Approval of the Method for Assessing the Expected Period of Funded Pension Payment' of 2 June 2015 no. 531]. Access from Reference Legal System 'KonsultantPlyus'(accessed May 6, 2018).

15. Proekt Federalnogo zakona № 489161-7 «O vnesenii izmeneniy $v$ otdelnye zakonodatelnye akty Rossiyskoy Federatsii po voprosam naznacheniya i vyplaty pensiy» [Draft Federal Law no. 489161-7 'On Amendments to Certain Legislative Acts of the Russian Federation on the Issues of Assignment and Payment of Pension']. Access from Reference Legal System 'KonsultantPlyus'(accessed September 1, 2018).

16. Pushkin A.S. Kapitanskaya dochka [The Captain's Daughter]. A.S. Pushkin. Sobr. soch. V10 t. T. 5 [Alexander Pushkin. Writings. In 10 vols. Vol. 5]. Moscow, 1959-1962, pp. 286-411.

17. Saltykov G.K. Pragmaticheskie svoystva yuridicheskikh terminov [Pragmatic Properties of Legal Terms]. Sovremennoe pravo, 2015, no. 8, pp. 26-31.

18. Semeynyy kodeks Rossiyskoy Federatsii ot 29 dek. 1995 g. № 223-FZ (red. ot 29 dek. 2017) [Family Code of the Russian Federation of 29 December 1995 no. 223-FZ (ed. of 29 December 2017)]. Sbornik osnovnykh federalnykh zakonov $R F$ [Collection of the Basic Federal Laws of the Russian Federation]. URL: https://fzrf.su/kodeks/ sk/ (accessed September 1, 2018).

19. Slobodyan E. Chto takoe srok dozhitiya? [What is the Endowment Period?]. Argumenty $i$ fakty, 2016, May 26. URL: http://www.aif.ru/ dontknows/actual/chto_takoe_srok_dozhiti. (accessed May 7, 2018).

20. Abramov N., ed. Slovar russkikh sinonimov $i$ skhodnykh po smyslu vyrazheniy [Dictionary of Russian Synonyms and Expression Similar in Meaning]. Moscow, Russkie slovari Publ., 1999. $433 \mathrm{p}$.

21. Sostoyanie zdorovya naseleniya v svyazi s sostoyaniem prirodnoy sredy $i$ usloviyami prozhivaniya naseleniya. Otsenka radiatsionnogo riska u naseleniya za schet dlitelnogo ravnomernogo tekhnogennogo oblucheniya $v$ malykh dozakh. 
Metodicheskie ukazaniya (MU 2.1.10.3014-12. 2.1.10) [Health Status of the Population Depending on the State of Natural Environment and Living Standards. Estimation of Radiation Risk in the Population due to Long-Term Uniform Technogenic Exposure in Small Doses. Methodological Guidance (2.1.10.3014-12.2.1.10)]. Access from Reference Legal System 'KonsultantPlyus' (accessed May 6, 2018).

22. Spenser G. Grekhi zakonodateley [Sins of Legislators]. Sotsiologicheskie issledovaniya, 1992, no. 2, pp. 129-136.

23. Tarasevich I.B. Adekvatnost yazyka zakona: avtoref. diss. ... kand. yurid. nauk [Adequacy of the Language of Law. Cand. jurid. sci. abs. diss.]. Moscow, $2018.28 \mathrm{p}$.

24. Ter-Minasova S.G. Yazyk i mezhkulturnaya kommunikatsiya [Language and Intercultural Communication]. Moscow, Slovo Publ., 2000. 261 p.

25. Federalnyy zakon «Ob obrazovanii v Rossiyskoy Federatsii» ot 29 dek. 2012 g. № 273-FZ (red. ot 29 dek. 2017) [Federal Law 'On Education in the Russian Federation' of December 29, 2012 no. 273FZ (ed. of December 29, 2017)]. Ofitsialnye setevye resursy Prezidenta Rossii [The Official Network Resources of the President of Russia] (accessed August 27, 2018).

26. Federalnyy zakon $" O$ vvedenii $v$ deystvie chasti tretyey Grazhdanskogo kodeksa Rossiyskoy Federatsii» ot 26 noyab. 2001 g. № 147-FZ [Federal Law 'On the Introduction of Part Three of the Civil Code of the Russian Federation' of November 26, 2001 no.147-FZ]. Access from Reference Legal System 'KonsultantPlyus' (accessed May 7, 2018).

27. Federalnyy zakon "O gosudarstvennom pensionnom obespechenii v Rossiyskoy Federatsii» ot 15 dek. 2001 g. № 166-FZ (red. ot 18 iyulya 2017 g.) [Federal Law 'On State Pension Provision in the Russian Federation' of December 15, 2001 no. 166FL (ed. of July 18, 2017)]. Access from Reference Legal System 'KonsultantPlyus' (accessed May 7, 2018).

28. Federalnyy zakon "O sotsialnoy zashchite invalidov v Rossiyskoy Federatsii» ot 24 noyab. 1995 g. № 181-FZ (red. ot 29 dek. 2017 g.) [Federal Law 'On Social Protection of Disabled People in the Russian Federation' of November 24, 1995 no. 181FZ (ed. of December 29, 2017)]. Access from Reference Legal System 'KonsultantPlyus' (accessed May 6, 2018).

29. Federalnyy zakon $« \mathrm{O}$ trudovykh pensiyakh v Rossiyskoy Federatsii» [Federal Law 'On Labor Pensions in the Russian Federation']. Rossiyskaya gazeta: Federalnyy vypusk, 2001, no. 2859. URL: https://rg.ru/2001/12/20/zakonpensii-dok.html. (accessed May 7, 2018).

30. Federalnyy zakon «O fizicheskoy kulture i sporte v Rossiyskoy Federatsii» ot 04 dek. 2007 g. № 329-FZ (red. ot 05 dek. 2017 g.) [Federal Law 'On Physical Culture and Sport in the Russian Federation' of December 4, 2007 no. 329-FZ (ed. of December 5, 2017)]. Sbornik federalnykh zakonov $R F$ [Collection of Federal Laws of the Russian Federation] URL: https:/ /fzrf.su/zakon/o-fizicheskoj-kulture-i-sporte-329-fz (accessed September 1, 2018).

31. Federalnyy zakon «Tekhnicheskiy reglament o bezopasnosti zdaniy i sooruzheniy» ot 30 dek. 2009 g. № 384-FZ (red. ot 02 iyulya 2013 g.) [Federal Law 'Technical Regulations on Safety of Buildings and Constructions' of December 30, 2009 no. 384-FZ (ed. of July 2, 2013)]. Access from Reference Legal System 'KonsultantPlyus' (accessed August 23, 2018).

\section{Information about the Authors}

Yuliya V. Chemeteva, Master Student, Department of Constitutional and Municipal Law, Volgograd State University, Prosp. Universitetsky, 100, 400062 Volgograd, Russian Federation, iuliiakazankova@mail.ru.

Marina L. Davydova, Doctor of Sciences (Jurisprudence), Professor, Head of Department of Constitutional and Municipal Law, Volgograd State University, Prosp. Universitetsky, 100, 400062 Volgograd, Russian Federation, davidovavlg@gmail.com.

\section{Информация об авторах}

Юлия Владимировна Чеметева, магистрант кафедры конституционного и муниципального права, Волгоградский государственный университет, просп. Университетский, 100, 400062 г. Волгоград, Российская Федерация, iuliiakazankova@mail.ru.

Марина Леонидовна Давыдова, доктор юридических наук, профессор, заведующая кафедрой конституционного и муниципального права, Волгоградский государственный университет, просп. Университетский, 100, 400062 г. Волгоград, Российская Федерация, davidovavlg@gmail.com. 